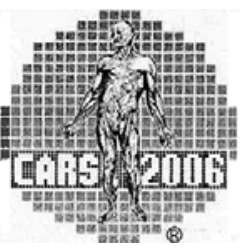

\title{
CARS 2006
}

Computer Assisted Radiology and Surgery $20^{\text {th }}$ International Congress and Exhibition Osaka, Japan June 28 - July 1, 2006

CARS 2006 - Computer Assisted Radiology and Surgery Joint Congress of CAR/CAD/CMI

Date: June 28 - July 1, 2006

Title: $\quad$ CARS 2006 - Computer Assisted Radiology and Surgery $20^{\text {th }}$ International Congress and Exhibition

Venue: $\quad$ Osaka, Japan

Information: CARS Conference Office

Im Gut 15

79790 Kuessaberg

Tel. : +49 7742922434

Fax : +497742922 438

E-mail : office@cars-int.org

www.cars-int.org

Deadline for submission of abstracts : January 10, 2006

For further information please refer to our home page at www.cars-int.org which will be updated regularly, or contact us at the address above. 